\title{
Letter to the Editor: Comments on "A New Method to Estimate Adult Age-at-Death Using the Acetabulum" (Calce, 2012)
}

In 2006, Rissech and collaborators proposed seven variables of the acetabulum (1, acetabular groove; 2 , rim shape; 3 , rim porosity; 4 , apex activity; 5 , activity on the outer edge of the rim fossa; 6 , activity of the acetabular fossa, 7, porosities of the acetabular fossa) for their use in adult age estimation. The method was based on a sample of 242 male individuals from the documented collection of Coimbra in Portugal. Each of the seven variables of the acetabular region was broken into different states describing the different morphological conditions of the acetabular region (e.g., acetabular groove can be scored as: no groove [0], groove [1], pronounced groove [2], and very pronounced groove [3]). The method's accuracy was tested using Bayesian inference (Rissech et al., 2006): results indicated the potential value or applicability of the seven variables, and $89 \%$ reliability was observed using Bayesian prediction. In 2007, the same authors tested the method proposed in 2006 (Rissech et al., 2007) based on 394 male individuals from four documented Western European collections: the Coimbra and Lisbon collections from Portugal, the UAB collection from Spain, and the St Bride collection from England. They concluded that although good results had been obtained and the acetabulum (and the seven proposed variables) therefore appeared to be a good indicator of age, population variability could be observed. All of these studies were complemented by an MS2 computer program of free distribution named IDADE 2, which was developed by the late Professor George Estabrook of the University of Michigan (Rissech et al., 2006) to facilitate calculations for age prediction by Bayesian inference. Now, IDADE2 program and the user's guide can be downloaded from http://www.ub.edu/biologiaicultura/ $? \mathrm{q}=$ node $/ 12$.

Recently, and using results obtained in the previous study of Calce and Rogers (2011), Ms. Calce proposed a new method of adult age estimation using the acetabulum. According to Calce (2012), she developed this new methodology due to the poor results obtained by Calce and Rogers (2011) upon testing Rissech et al.'s method. Apart from being summarized in Calce (2012), these criticisms of Rissech et al.'s (2006) method are found in detail in Calce and Rogers (2011).

In their first article, Calce and Rogers (2011) evaluate the method of Rissech et al. (2006) using a sample of 100 male individuals from the Grant collection from the University of Toronto, Canada. Also, the authors add four more Western European collections (the original data of Coimbra, Lisbon, UAB, and St Brides scored by Rissech et al.) to undertake their test; they use these collections as reference samples to estimate the age of the Grant collection (test sample) with IDADE2. In their study, Calce and Rogers explicitly state that the authors of the original article (Rissech et al.) supplied them with the original data from these four Western European collections. It is true that the original data were sent to Calce personally by the first author (Dr. Rissech). However, it is necessary to clarify two points:

1. When she was sent the original data of the four Western European collections, Ms. Calce was informed that the data could not be used to carry out any comparison, or as a reference sample in the age estimation of another sample. The reason was that the system of coding of the seven acetabular variables differed between the raw data and the published results: the different states of the seven variables had been recoded in the publication in order to make the code system more comprehensible to the reader. During the course of her original research, Dr. Rissech found that certain numerical states were not exhibited in the remains under study. Thus, as her research progressed, some of the different states of each variable were eliminated or merged; to enhance comprehension, the definition of the variables in the first paper reflected this recoding of the original data. For example, State 3 of variable 1 in the original data corresponds to State 2 of variable 1 in the published code, due to the lack of State 2 in the original data. Due to these code differences in the states or degrees of expression of each variable between the reference sample (Western European collections) and the test sample (Grant collection), the results presented by Calce and Rogers (2011) are not exactly correct, and consequently the population differences and the erroneous estimates in their study between these two samples (pages 308-310 of their paper) are probably exaggerated.

2. Calce and Rogers (2011) did not request permission to use the data in their publication; and neither Rissech nor any of her collaborators received any notification before the data appeared in their 2011 publication (Calce and Rogers, 2011).

There can be little doubt that inconsistent coding would affect, if not invalidate, Calce and Rogers' (2011) findings. However, Calce (2012) insists that only three (acetabular groove, rim porosity, and apex activity) of

*Correspondence to: Carme Rissech, Physical Anthropology Unit, Department of Animal Biology, Faculty of Biology, University of Barcelona, Av. Diagonal, 645. 08028 Barcelona, Spain. E-mail: carme.rissech@ub.edu

Received 8 October 2012; accepted 20 February 2013

DOI: 10.1002/ajpa.22265

Published online 00 Month 2013 in Wiley Online Library (wileyonlinelibrary.com). 
the variables defined by Rissech et al. correlate with chronological age (Calce 2012, p 12); and after considerable statistical analysis Calce (2012) arrives at the basic result of classifying the individuals by the acetabular morphology into three age groups: young adult (17-39 years), middle adult (40-64 years), and old adult (over 65 years). Contrary to Calce's conclusions, we urge caution in applying this method to bioarchaeological and forensic investigations. The problem is this: in a contingency table approach to age estimation, age classes (e.g., 17-39, 40-64, and 65+) from one indicator are unlikely to align with any other indicator, rendering the acetabulum data unable to be combined with anything else (compare to Lucy et al.'s (1996) Table 1, which lists a number of indicators against the same age classes). Furthermore, with its few and broad age intervals, Calce's method is accurate, but not precise. Whether interpreted in a forensic or an archaeological context, an adult of 38 years of age is not the same as a sub-adult of 18; however, this method places them both in the same age class (17-39). In addition, the claim that "methods using the acetabulum to estimate age have not employed Bayes' theorem to correct this problem" (she is referring to the "mimicry" problem) seems to be contradictory to the work of Calce (See "A holistic approach to scoring age-related traits" section in Calce's paper page 20) because Calce herself used Bayes inference in Calce and Rogers' (2011) paper. Information on the methods of adult age estimation, their limitations and the "mimicry" problem can be found in Bocquel-Appel and Masset (1982, 1985), Konigsberg and Frankenberg (1992), Wood et al. (1992), Hoppa and Vaupel (2002), Milner et al. (2008), Milner and Boldsen (2012), Rissech et al. (2012), San Millán et al. (2013), among others.

It would be scientifically important if Calce had considered that the results obtained could be due to population variation. Population variation has been previously noted by Rissech et al. (2007), although this variation (as well as sex differences) has not yet been analyzed in detail. The skeletal materials analyzed by Rissech et al. in their two studies $(2006,2007)$ mainly originate from the Iberian Peninsula. In the 2007 article, Rissech et al. observed that these individuals presented a similar aging pattern, whereas the aging pattern of the English sample was different (see page 777 in the Discussion section of Rissech et al., 2007). Although these differences are not commented on in this article, they mainly consist of the formation of a crest on the acetabular rim, and the proliferation of porosities and later bone formation in the acetabular fossa in the Iberian individuals; the English sample (along with Scottish individuals-data not published) did not exhibit this tendency. This pattern, which we can call Iberian, has also been observed very recently by Dr. Rissech in modern Colombian innominates (data not published). This similarity between the Iberian pattern and the pattern observed in the innominates of the modern Colombian population could be explained by the recent historical and biological relationship between these two countries (Colombia and Spain) after European contact. Perhaps these differences between the populations (Iberian and non-Iberian) are caused by genetic differences that result in some individuals producing more bone than others. In fact, these differences have already been described in males and females (Schneider et al., 2002; Schmitt et al., 2007), with males having a tendency to form more bone (bone producers) and females a tendency to lose it (bone losers).
It is absolutely essential, before using the acetabular method indiscriminately, to study in depth the possible differences that may exist in the variables of this age marker between different populations and sexes and to try to understand their biology and aging process.

\section{ACKNOWLEDGEMENTS}

The author thanks Nicholas Márquez-Grant from the University of Oxford, Allisha P. Winburn from the University of Florida and the three referees and the editors for their useful comments.

CARME RISSECH
Department of Animal Biology
Physical Anthropology Unit, Faculty of Biology
University of Barcelona, 08028 Barcelona, Spain

\section{LITERATURE CITED}

Bocquel-Appel JP, Masset C. 1982. Farewell to paleodemography. J Hum Evol 11:321-333.

Bocquel-Appel JP, Masset C. 1985. Paleodemography: resurrection or ghost? J Hum Evol 14:107-111.

Calce SE. 2012. A new method to estimate adult age-at-death using the acetabulum. Am J Phys Anthropol 148:11-23.

Calce SE, Rogers TL. 2011. Evaluation of age estimation technique: testing traits of the acetabulum. J Forensic Sci 56:302-311.

Hoppa RD, Vaupel JW. 2002. The Rostock Manifesto for paleodemography: the way from stage to age. In: Hoppa SP, Vaupel JW, editors. Paleodemography: age distributions from skeletal samples. Cambridge: Cambridge University Press. p 1-8.

Konigsberg LW, Frankenberg SR. 1992. Estimation of age structure in anthropological demography. Am J Phys Anthropol 89:235-256.

Lucy D, Aykroyd RG, Pollard AM, Solheim T. 1996. A Bayesian approach to adult human age estimation from dental observations by Johanson's age changes. J Forensic Sci 41:189-194.

Milner GR, Boldsen JL. 2012. Estimating age and sex from the skeleton, a paleopathological perspective. In: Grauer AL, editor. A companion to paleopathology. Chichester: Wiley Blackwell. p 268-284.

Milner GR, Wood JW, Boldsen JL. 2008. Advances in paleodemography. In: Katzenberg MA, Saunders SR, editors. Biological anthropology of the human skeleton. Hoboken, NJ: Wiley Liss. p 561-600.

San Millán M, Rissech C, Turbón D. 2013. A test of SucheyBrooks (pubic symphysis) and Buckberry-Chamberlain (auricular surface) methods on an identified Spanish sample: paleodemographic implications. J Archaeol Sci 40:1743-1751.

Rissech C, Estabrook GF, Cunha E, Malgosa A. 2006. Using the acetabulum to estimate age-at-death of adult males. J Forensic Sci 51:213-229.

Rissech C, Estabrook GF, Cunha E, Malgosa A. 2007. Estimation of age-at-death for adult males using the acetabulum, applied to four Western European populations. J Forensic Sci 52:774-778.

Rissech C, Wilson J, Winburn A, Steadman D, Turbón D. 2012. A comparison of three established age estimation methods on an adult Spanish sample. Int J Legal Med 126:145-155.

Schmitt A, Wapler U, Couallier V, Cunha E. 2007. Are bone losers distinguishable from bone formers in a skeletal series? Implications for adult age at death assessment methods. Homo 58:53-66.

Schneider DL, Barrett-Connor E, Morton DJ, Weisman M. 2002. Bone mineral density and clinical hand osteoarthritis in elderly men and women: the Rancho Study. J Rheumatol 29:1467-1472.

Wood JW, Milner GR, Harpending HC, Weiss KM. 1992. The osteological paradox: problems of inferring prehistoric health from skeletal samples. Curr Anthropol 33:343-370. 